\section{$\gamma$ A gene repeats polymorphism for the analysis of haplotypes of abnormal hemoglobins}

\author{
Nejat Akar, Kadir Sipahi, Ece Akar, \\ Erkan Yilmaz \\ Department of Pediatric Molecular \\ Genetics, Ankara University, \\ Ankara, Turkey
}

\section{Abstract \\ Aim of this study was to analyze $\gamma$ A gene repeat polymorphism for the analysis of haplo- types of hemoglobin $(\mathrm{Hb})$ variants such as $\mathrm{Hb}$ S, Hb D-Punjab, Hb 0-Arab. Sickle cell cases had mainly Benin and Arab/Indian haplotype. We found three different haplotypes among $\mathrm{Hb}$ $\mathrm{S}$, Hb $\mathrm{O}$ Arab and $\mathrm{Hb}$ D-Punjab cases. We named these three variants as Anatolian-1 and Anatolian-2 and Asian. Our data revealed that $\mathrm{Hb} O \mathrm{Arab}$ may arise twice one from Asia and the other from Europe. \\ $\gamma \mathbf{A}$ gene repeats polymorphism for the analysis of haplotypes of abnormal hemoglobins}

Turkey is situated at the meeting point of three continents of the world and stands as a crossroad between Asia and Europe. Due to its geographical location, Anatolia has historically been in contact with various races and ethnic groups. Although Turks originated mainly in central Asia, they probably mixed with the people formerly living in Asia Minor, Africa and those living in the Balkan countries. Therefore it is not surprising to find numerous examples of hemoglobin $(\mathrm{Hb})$ variants in Turkey today as previously reported. Most common variants are hemoglobin S (B6 Glu-Val), Hb D Punjab (B121 Glu-Gln), Hb 0 Arab (B121 Glu-Lys) and Hb E Saskatoon (B22 Glu-Lys). ${ }^{1-3}$

Previously it was reported that a unique repetitive sequence at the $\gamma$ A gene IVS-II of the $\beta$-S globin chain can discriminate African haplotypes of $\mathrm{Hb} \mathrm{S}$. These reports analyzed the haplotypes and gave the sequences as follows: Benin (TG)10CGCGCGCG(TG)7TC; Bantu (TG)10(CG)3(TG)9TC; Senegal (TG)13TC; Arab-India (TG)13TC and Cameroon (TG)12(CG)3(TG)7TC. ${ }^{4,5}$

We aimed to sequence the $\gamma$ A gene IVS-II region of the $\beta$ globin gene for hemoglobin $S$ and other common hemoglobin variants in Turkish population.

\section{Materials and Methods}

We analyzed individuals with hemoglobin variants $\mathrm{Hb} \mathrm{S}$ (n:11) , Hb D Los Angeles (n: 10), Hb 0 Arab (N:12), Hb C, Hb E Saskatoon, and $\mathrm{Hb}$ Beograd ( $\beta 121(\mathrm{GH} 4) \mathrm{Glu}>\mathrm{Val})$ for the $\gamma$ A gene IVS-II single-nucleotide polymorphism (SNP). These hemoglobin variants were diagnosed by $\beta$ globin gene sequencing of the exons 1, 2 and 3 (Beckman Coulter 2000; Beckman Coulter, Inc., Brea, CA, USA). Sequencing of the $\gamma$ A gene IVS-II was performed by the primers $F$, TGCTGCTAATGCTTCATTACAA 3' and R 5' TAAATGAGGAGCATGCACACAC 3 ' as previously reported. ${ }^{4,5}$

\section{Results}

Our data revealed that six of the $\mathrm{HbS}$ case had Benin TG(10)CG(2)CACGTG(7), and one of them had Senegal/Arab-India TG(13) haplotype. Four of them carried TG(10)CG(5)TG(5) which was not found in African haplotypes. All of the Hb D Punjab cases carried TG(9)CG(5)TG(8). $\mathrm{Hb} 0$ Arab carriers had either TG(9)CG(5)TG(8) or TG(10)CG(5) TG(7). Hb E Saskatoon, and Hb Beograd cases had TG(9) CG(5) TG(8) as similar to $\mathrm{Hb} \mathrm{D}$ Punjab cases.

\section{Discussion and Conclusions}

It is well known that hemoglobin variants may show the historical immigration routes of humans. SNP's may as well have the same property. Our data revealed that most of the $\mathrm{Hb} \mathrm{S}$ cases are of African origin. Most of them are Benin type and rarely Senegal/Arab Indian type. We did not observed Cameroon type in our sickle cell patients. However in four cases, we detected a haplotype, which did not show any similarity for other previously reported four haplotypes. This haplotype needs further study in more cases. This may be indicative of another mutation arise for hemoglobin $\mathrm{S}$. It is interesting that
Correspondence: Nejat Akar, TOBB-Economy and Technology University Hospital, Pediatrics, Koru Mah, 2621.sokak, Uyum Sitesi 18, Çayyolu/ Ankara,Turkey.

E-mail: akar@medicine.ankara.edu.tr

Key words: hemoglobin, sickle cell disease, hemoglobin D-Punjab, repetitive sequence, $\mathrm{Hb} \mathrm{O}$ Arab, haplotype.

Conflict of interests: authors declare that they have no conflict of interests.

Received for publication: 20 September 2013.

Revision received: 14 January 2014.

Accepted for publication: 11 February 2014.

This work is licensed under a Creative Commons Attribution 3.0 License (by-nc 3.0).

CCopyright N. Akar et al., 2014

Licensee PAGEPress, Italy

Thalassemia Reports 2014; 4:1935

doi:10.4081/thal.2014.1935

our Hb D Punjab cases carried only one distinct haplotype. This may be a clue for the immigration of people with a route from northern India to Anatolia. Previously our group reported three different haplotypes mainly Mediterranean haplotype but in one case Thai haplotype. Based on this data we claimed that this finding might reflect different genetic origins and/or other molecular events like gene conversions or gene rearrangements..$^{6-9}$ However our present data revealed a distinct one origin, may be reflecting an Asian founder effect. Hb E Saskatoon and $\mathrm{Hb}$ Beograd carriers had similar haplotype to Hb D Punjab. The haplotypes of the two hemoglobins may also show immigration from Asia to Europe. We observed two different haplotypes for $\mathrm{Hb} 0$ Arab cases. This finding indicates that $\mathrm{Hb} \mathrm{O}$ Arab cases may have two different origins, one possibly Asia and other from Africa. There is a great similarity between the new haplotype we observed in our sickle cell cases. The other haplotype is the same as $\mathrm{Hb}$ D Punjab cases indicating Asian origin. We named these three different variants as Asian, Anatolian-1 and Anatolian-2 (Table 1).

A previous report from Greek Pomaks

Table 1. $\gamma$ A gene repetitive sequence analysis of hemoglobin variants.

\begin{tabular}{lccc} 
Haplotype & \multicolumn{1}{c}{ Sequence } & No. & Hb \\
Benin & $\mathrm{TG}(10) \mathrm{CG}(2) \mathrm{CACG} \mathrm{TG}(7)$ & $\mathrm{Hb} \mathrm{S}$ & 6 \\
Senegal/Arab-India & $\mathrm{TG}(13)$ & $\mathrm{Hb} \mathrm{S}$ & 1 \\
\hline Anatolian-1 & $\mathrm{TG}(10) \mathrm{CG}(5) \mathrm{TG}(5)$ & $\mathrm{Hb} \mathrm{S}$ & 4 \\
Asian-1 & $\mathrm{TG}(9) \mathrm{CG}(5) \mathrm{TG}(8)$ & Hb D Punjab & 9 \\
& & Hb O Arab & 4 \\
& & Hb Beograd & 1 \\
& & Hb E Saskatoon & 1 \\
\hline Anatolian-2 & $\mathrm{TG}(10) \mathrm{CG}(5) \mathrm{TG}(7)$ & Hb O Arab & 8 \\
\hline
\end{tabular}

Hb, hemoglobin. 
claimed a marked high incidence of $\mathrm{Hb} 0 \mathrm{Arab}$ and difference of the Greek mainland haplotypes. How ever, their theory may not be true as Pomaks not only exist in Greece but also mainly in Bulgaria dispersed in Balkans. Pomaks are Slav originated Muslims, which may be a clue for the admixture to 0ttomans. ${ }^{10}$ This point needs further clarification for the Greek Pomaks by using this repetitive sequence. Our data probably opens a new era for the ancestry of abnormal hemoglobins, indicating more concise analysis with more cases.

\section{References}

1. Altay Ç. Abnormal hemoglobins in Turkey.
Turk J Hematol 2002;19:63-74.

2. Akar E, Akar N. A review of abnormal hemoglobins in Turkey. Turk $\mathrm{J}$ Hematol 2007;24:143-5.

3. Akar N. An update review of abnormal hemoglobins in Turkish Population. Turk J Hematol 2014;31:97-8.

4. Vinson AE, Walker A, Elam D, et al. A novel approach to rapid determination of bS-globin haplotypes: sequencing of the A g-IVSII region. Hemoglobin 2004;28:317-23.

5. Lanclos KD, Oner C, Dimovski AJ, et al. Sequence variations in the 5' flanking and IVS-II regions of the $\mathrm{G} \gamma$ - and A $\gamma$-globin genes of $\beta \mathrm{S}$ chromosomes with five different haplotypes. Blood 1991;77:2488-96.

6. Öztürk 0, Atalay A, Köseler A, et al. globin gene cluster haplotypes of abnormal hemoglobins observed in Turkey. Turk J
Hemat 2007;24:146-54.

7. Bahadır A, Köseler A, Atalay A, et al. Hb DLos Angeles [ $\beta 121(\mathrm{GH} 4) \mathrm{Glu}>\mathrm{Gln}]$ and $\mathrm{Hb}$ Beograd [ $\beta 121(\mathrm{GH} 4) \mathrm{Glu}>\mathrm{Val}$ ]: implications for their laboratory diagnosis and genetic origins. Turk J Hemat 2009;26:17-20.

8. Fioretti G, De Angioletti M, Pagano L, et al. DNA polymorphisms associated with $\mathrm{Hb} \mathrm{D}$ Los Angeles [B121 (GH4) Glu Gln] in Southern Italy. Hemoglobin 1993;17:9-17.

9. Fucharoen S, Changtrakun Y, Surapot S, et al. Molecular characterization of $\mathrm{Hb} \mathrm{D}$ Punjab [ $\beta 121(\mathrm{GH} 4) \mathrm{Glu} \longrightarrow \mathrm{Gln}]$ in Thailand. Hemoglobin 2002;26:261-9.

10. Papadopoulos V, Dermitzakis E, Konstantinidou D, et al. HbO-Arab mutation originated in the Pomak population of Greek Thrace. Haematologica 2005;90:255-7. 